\title{
Hazards and disasters in the geological and geomorphological record: a key to understanding past and future hazards and disasters
}

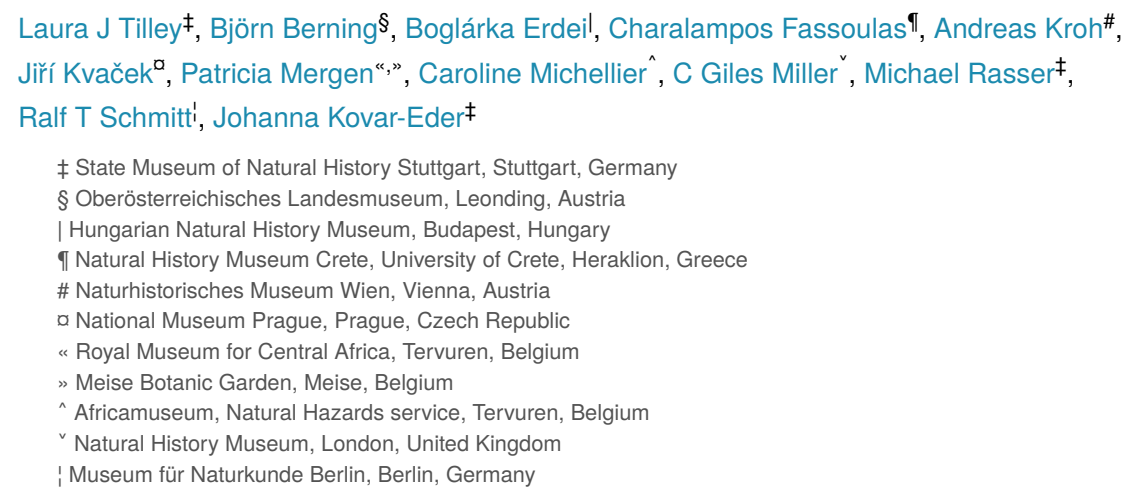

Corresponding author: Laura J Tilley (laura.tilley@smns-bw.de), Björn Berning (b.berning@landesmuseum.at), Boglárka Erdei (erdei.boglarka@nhmus.hu), Charalampos Fassoulas (fassoulas@nhmc.uoc.gr), Andreas Kroh (andreas.kroh@nhm-wien.ac.at), Jiří Kvaček (jiri.kvacek@nm.cz),Patricia Mergen (patricia.mergen@africamuseum.be), Caroline Michellier (caroline.michellier@africamuseum.be), C Giles Miller (g.miller@nhm.ac.uk), Michael Rasser (michael.rasser@smns-bw.de), Ralf T Schmitt (ralf-thomas.schmitt@mfn.berlin), Johanna Kovar-Eder (johanna.eder@smns-bw.de)

Received: 25 Feb 2019 | Published: 07 Mar 2019

Citation: Tilley L, Berning B, Erdei B, Fassoulas C, Kroh A, Kvaček J, Mergen P, Michellier C, Miller C, Rasser M, Schmitt R, Kovar-Eder J (2019) Hazards and disasters in the geological and geomorphological record: a key to understanding past and future hazards and disasters. Research Ideas and Outcomes 5: e34087.

\section{Abstract}

Hazards and disasters have occurred throughout Earth's History and thus the geological record is an important resource for understanding future hazards and disasters. The Earth Science Group (ESG) of the Consortium of European Taxonomic Facilities (CETAF) carried 
out a "Hazard and Disaster Event Survey" to identify Earth Science collections in European museums that represent hazards and disasters throughout the geological record, and recent times. The aim is to use the collections within the survey as an educational and research resource that promotes the importance of museum collections for understanding past and future hazard and disaster events. The survey pinpointed a wide variety of hazards (e.g. earthquakes, volcanism, floods, impact events, etc.), representing a vast time span in Earth's history (Proterozoic to Holocene), that are documented in the collections of the participating museums. Each hazard and disaster event has been described in terms of how they are preserved (e.g. fossil record or rock record), spatial scale, impact on life, and geological age. Here we showcase seven examples in detail which include well-known and less-known events from the survey that have contributed to our understanding of hazard and disaster processes and their impact on life. Also we present general conclusions and lessons learnt from the "Hazard and Disaster Event Survey".

\section{Keywords}

Hazards, Disasters, Earth Science, Museum collections, Geological record, Fossils, Rocks, Minerals

\section{Introduction}

According to the Centre for Research on the Epidemiology of Disasters (2009), a hazard is a threatening event, which can be biological (e.g. bacteria and viruses), climatological (e.g. atmospheric processes that cause climate variability), extraterrestrial (e.g. impact events), geological (e.g. volcanic eruptions and earthquakes) or hydrological (e.g. floods and tsunamis). The definition of a disaster according to the United Nations Office for Disaster Risk Reduction (2009) is a "serious disruption of the functioning of a community or society involving widespread human, material, economic or environmental losses and impacts, which exceeds the ability of the affected community or society to cope using its own resources."

At present, there is widespread research (IPCC 2014) indicating that human activity is having an effect on the Earth's climate and as a direct result this is increasing the frequency and magnitude of some types of hazards. Some of the likely future hazards indicated by the International Panel of Climate Change (IPCC) include: a higher frequency and magnitude of flood events in some regions as a result of sea level rise and storms; increased risk of landslides/mass movement caused by heavy rainfall; extinction of many marine organisms particularly in tropical regions due to marine anoxia and ocean acidification; and more regular heat waves and drought events.

The frequency and magnitude of natural processes such as volcanic eruptions, earthquakes, and tsunamis are not a consequence of climate change or human activity, but their potential impacts are worsened due to the increasingly exposed human population 
(Huppert and Sparks 2006). This is a consequence of communities and livelihoods being built in areas prone to these events (e.g. unstable slopes, coastal areas, living close to volcanoes centres, etc.). The alteration of natural landscapes by human activity can also increase the occurrence of hazards (e.g. deforestation increasing the probability of landslides).

Hazards have occurred throughout Earth's history. The geological and geomorphological records are important resources for understanding past and future hazards and disaster events. Earth scientists are able to study the rock record (sedimentology, petrology, geophysics and geochemistry) and the fossil record (the study of ancient fauna and flora) to investigate the processes of hazard events in order to improve forecasts and to anticipate the impact on life and its recovery afterwards.

This article has been developed by the Earth Science Group (ESG) of the Consortium of European Taxonomic Facilities (CETAF). The ESG consists of multiple museums and other research institutions within Europe, and its main purpose is to promote the importance of Earth Science collections in facilitating a better understanding and forecasting of current environmental and biodiversity issues. To help fulfil this purpose the ESG carried out a "Hazard and Disaster Event Survey" (presented in Suppl. material 1) to identify Earth Science collections within its institutes that allow the study of causes and effects of hazards and disasters through geological time. The aim of the survey is to use the collections documented as a resource for educational and research purposes, for instance:

1. Increase awareness amongst the general public about hazards and how the geological and geomorphological records can be used to understand their impacts, and help learn lessons for the future.

2. To facilitate collaboration between researchers working on such events and help improve the robustness of existing data and models.

The "Hazard and Disaster Event Survey" includes a wide variety of events that have affected Earth at different geographical scales (local, regional and global) such as earthquakes, tsunamis, flooding, marine anoxia, volcanic eruptions and landslides. The geological age of the different hazards recorded in the survey spans an interval from the Proterozoic (2500 to 541 million years ago) to the Holocene $(11,700$ years to present day). Here we showcase a small number of hazard and disaster events including well-known and less-known ones recorded in the survey that have contributed to our understanding of hazard processes and their impact on life. A summary table of the "Hazard and Disaster Event Survey" is presented at the end of this article in the conclusions. It should be noted that this publication demonstrates the potential of museum collections, and that the "Hazard and Disaster Event Survey" is an incomplete record but will continue to expand.

Fig. 1 is a visualisation of the main types of hazards and disasters documented in the survey and how they are preserved in the geological record, the relationship between geographical scales at which they can occur, event duration, and magnitude of destruction to life. 


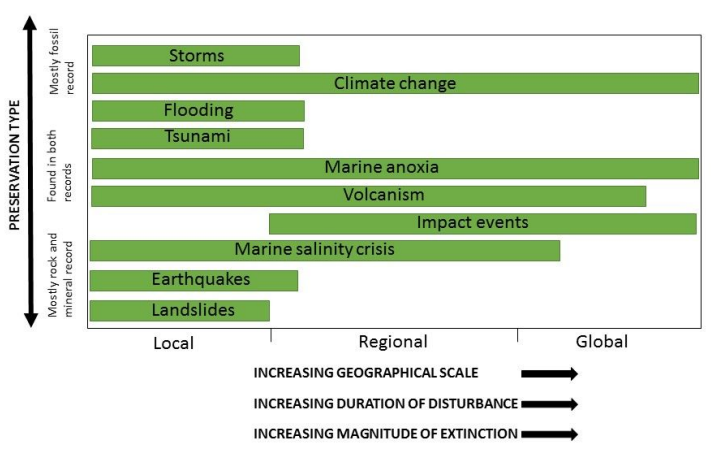

Figure 1. doi

Visualisation of the different types of hazards and disasters documented in the "Hazard and Disaster Event Survey".

\section{Explanation of hazards mentioned}

Volcanic eruption events: There are two main types of volcanic eruptions that have different hazards associated with them:

Explosive (e.g. Plinian and Vulcanian): These types of volcanic eruptions characteristically associated with evolved viscous magmas (e.g. andesitic and rhyolitic) with a high content of trapped volatiles, and when these magmas degas they produce explosive eruptions often projecting material into the stratosphere (Ball 2008, Nelson 2015). The volcanoes with this kind of magma and eruption style tend to be steep sided and occur in the vicinities of subduction zones (e.g. Andes volcanic belt, Chile/Argentina) (Stern 2004). Associated hazards include pyroclastic fallouts, pyroclastic flows, lahars (occur during and after the eruption and are similar to mud and debris flows, they consist of a mixture of water and loose volcanic derived material, organic material, man-made objects), rock ejection (e.g. pumice, hot rock fragments), and the release of poisonous gases (including $\mathrm{CO}_{2}$ ).

Non-explosive (e.g. Hawaiian, deep water submarine and Flood Volcanism): These types of eruptions are characterised by the outpouring of low viscosity magma (basaltic). Two examples of currently active volcanoes are Kilauea (Hawaii) and Nyiragongo (Democratic Republic of the Congo) (Barrière et al. 2018, United States Geological Survey 2018, Wauthier et al. 2012). A common example of basaltic volcanism is at mid-ocean ridges where magma is erupted to the Earth's surface and forms new ocean floor (Ball 2008). In Earth's past there have been flood basalt events, where very large volumes of magma have been erupted usually during times of increased continental drift (e.g. the Siberian Traps - Permian/Triassic boundary). These flood volcanism events are thought to have caused climate change and mass extinctions (Bond and Wignall 2014). Overall hazards of 
non-explosive events include the direct effect of hot lava flows, fire fountains and the release of poisonous gases (including $\mathrm{CO}_{2}$ ).

Flood events: The definition of a flood is "an overflow of a large amount of water beyond its normal limits especially over what is normally dry land," (English Oxford Living Dictionaries 2018). A flood event can occur in the vicinity of lakes, rivers and oceans, and they can be fast occurring (within a few hours) or gradual events (over years). Fast initiated flood events are sometimes called flash floods and can be the result of heavy rainfall or the failure of dams (natural or man-made) (Kvočka et al. 2016). An example, of gradual flooding is sea-level rise, which can flood low-lying land and can be caused by thermal expansion of the the ocean floor or melting of continental ice caps due to global warming (IPCC 2014, Kvočka et al. 2016).

Impact event: "A type of extraterrestrial hazard caused by the collision of the Earth with a meteoroid, asteroid or comet" (Centre for Research on the Epidemiology of Disasters 2009). Extraterrestrial projectiles vary in size, from very small (a few millimeters) to very large (e.g. the one that was likely to have caused the Cretaceous/Paleocene mass extinction is thought to have been approximately $9 \mathrm{~km}$ in diameter) (Kaiho and Oshima 2017, Arizona State University Center for Meteorite Studies 2018).

Salinity crisis: Occurs in bodies of water that are landlocked, without a continuous influx of fresh water and were evaporation exceeds inflow rate. This may result in the body of water becoming hypersaline (water with a higher salinity than sea water, and deposition of salt deposits) (Krijgsman et al. 1999, McGenity and Oren 2012). A modern example of a hypersaline basin is the Dead Sea (McGenity and Oren 2012).

Marine anoxia: Marine anoxic events occur when there is an absence or low level of oxygen in the water column, this can be due to sluggish ocean circulation during times of warmer climates where the deep ocean is not ventilated by the sinking of oxygen rich surface waters (Keeling et al. 2010, Bond and Grasby 2017). They can also be caused by an increased influx of nutrients from the continent leading to increased productivity of marine organisms and thus high oxygen consumption during the decay of organic matter.

\section{Local and regional scale hazards and disasters}

A local scale hazard/disaster event is defined here as one that affects a small geographical area (e.g. the size of a village, town or city). Whereas a regional scale hazard/disaster event affects a larger geographical area (e.g. a country or continent). Local and regional scale hazards/disasters of different types have been documented in the survey (see Suppl. material 1). Regional hazard/disaster events include: earthquakes, impacts, tsunamis, marine anoxia and salinity events. These different types of events are preserved in either the rock record or the fossil record, or both. For instance, impacts caused by extraterrestrial projectiles can be preserved in both records, in the rock record in the form of craters in the landscape, impact tektites and shocked quartz, etc.; or recorded in the fossil record by the destruction they have caused to life (e.g. inferred from plant remains, fossil vertebrate and 
invertebrate record). Another example is volcanic activity which is recorded in the rock record as pumice, ash layers, and lava flows but can also be represented by, for example, charcoalified plant remains. Evidence from the collections indicate that some regional hazards have not caused extreme destruction to life and the environment, but instead have created new habitats and helped initiate the evolution of new species. Below are more detailed examples (from the surveyed collections) of regional hazards/disaster events: two volcanic events, a flood event, two impact events, and a salinity crisis along with photos of museum collection specimens. Also other examples of less well-known local and regional events are given for each hazard/disaster type mentioned.

\section{Flood events}

\section{Bükkábrány drowned forest}

Age: 7 million years ago, Miocene (Kázmér 2008)

Modern location of event: Bükkábrány, north eastern Hungary

Location of collection: Hungarian Natural History Museum, Visitor Center of the Ipolytarnóc Fossils Nature Reserve

Preservation type: Palaeontology, fossil plants - tree stumps, fruits, seeds and leaves

Duration of event: Hundreds of years (Gross et al. 2011)

Impact on life: The rising water level of Lake Pannon drowned the swamp forests that grew around its edge.

Background story: The Bükkábrány fossil forest is considered to be unique because it is the oldest forest preserved in situ (life position) (Fig. 2), in which the wood of the tree stumps is still preserved in organic form, instead of petrified (organic material replaced by minerals)Kázmér (2008), Császár et al. (2009). The fossil forest was discovered when the area was exploited for lignite. Around 16 tree stumps were excavated in an area of 50 by $100 \mathrm{~m}$. The basal diameters of the tree trunks range from 1.8 to $3.6 \mathrm{~m}$ and they have a maximum height of $6 \mathrm{~m}$ Kázmér (2008), Császár et al. (2009).

The fossil tree trunks are the remains of a warm temperate swamp forest that consisted of mainly large coniferous trees (tree types: Glyptostrobus and Taxodium) (Erdei et al. 2009, Gryc and Sakala 2010). The forest was situated on the northern margin of an extensive ancient lake called Lake Pannon (Fig. 3). The forest is thought to have been similar to present day Taxodium forests in southeastern United States (Erdei and Magyari 2011). Around 7.5 million years ago the water level of Lake Pannon increased rapidly, and the marginal areas around the lake were flooded, which resulted in the drowning of the swamp forest (Kázmér 2008). The lower $6 \mathrm{~m}$ of the trees were covered by fine grey sands that filled cracks in the wood and prevented exposure to oxygen and thus bacterial decomposition (Kázmér 2008). Based on studies of the lake sediments the rising water 
level may have been caused by astronomically induced climate cycles (Milankovitch Cycle) or tectonics (Kázmér 2008, Gross et al. 2011).

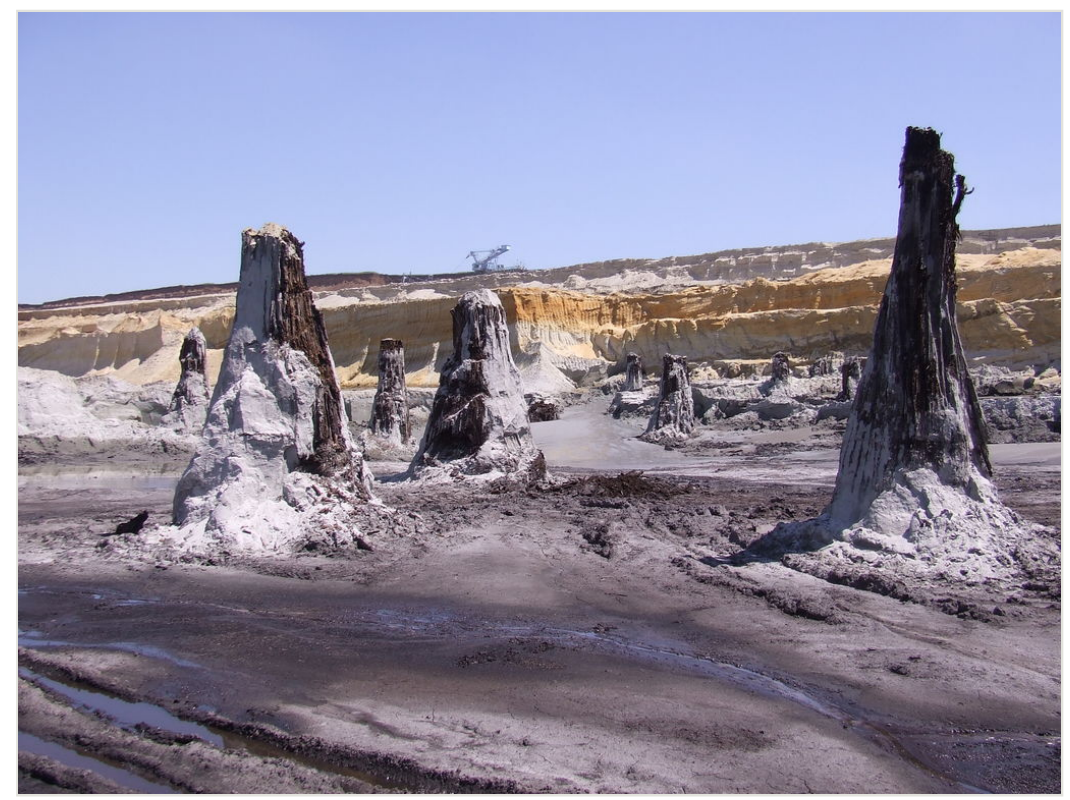

Figure 2. doi

The in situ tree stumps excavated in the lignite mine at Bükkábrány. Photo courtesy of B. Erdei, Hungarian Natural History Museum.

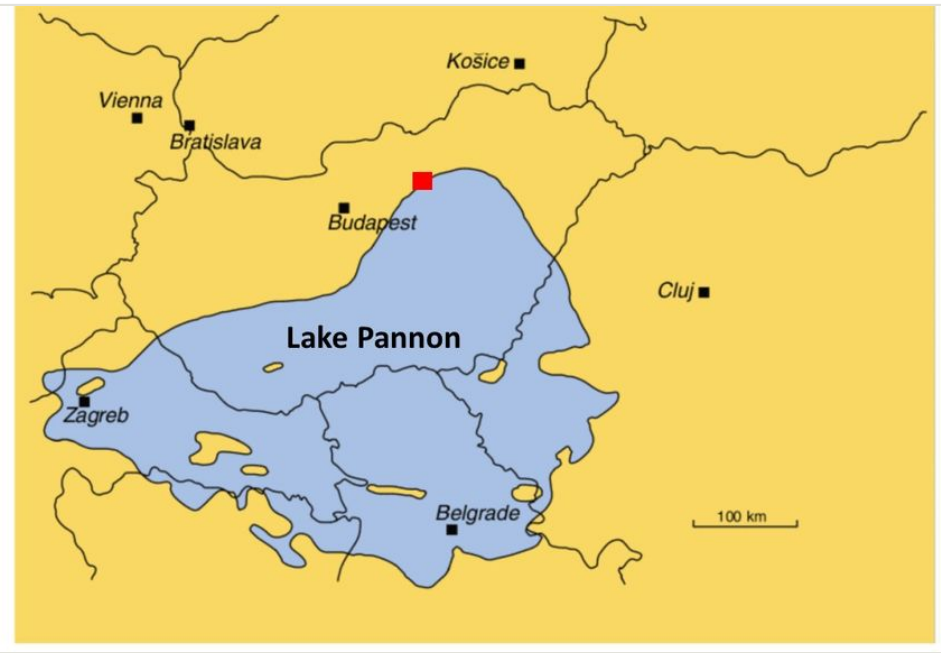

Figure 3. doi

A map showing the extent of Lake Pannon during the late Miocene and the location of the Bükkábrány forest which is highlighted by a red square. Modified from Magyar et al. (1999). 
These fossil tree stumps are a valuable tool for reconstructing the ancient swamp forest ecology and the climate conditions under which it occurred through the study of the wood anatomy (e.g. tree ring analysis) (Kázmér 2008). This may help gain insight into environmental conditions before and during the water level rise of Lake Pannon and could help to better understand what triggered the event.

\section{Other examples of local and regional scale flood events}

- A mammal collection (including a human cranium of Homo steinheimensis) of Pleistocene age, originating from Germany (stratigraphy: Holstein Interglacial and Riss Glacial Stage), and housed at the State Museum of Natural History Stuttgart.

- A vertebrate collection of late Miocene age, originating from Baltavár (Hungary), and housed at the Hungarian Natural History Museum.

\section{Impact events (extraterrestrial projectiles)}

\section{Ries and Steinheim impact events}

Age: $14.808 \pm 0.021$ million years ago, Miocene (Schmieder et al. 2018)

Modern location of event: Ries: Nördlinger Ries, Bayern Baden-Württemberg, Germany; Steinheim: Swabian Alb, Bayern and Baden-Württemberg, Germany

Location of collection: Ries: Museum für Naturkunde Berlin, Natural History Museum Vienna; Steinheim: Museum für Naturkunde Berlin, State Museum of Natural History Stuttgart, Natural History Museum Vienna

Preservation type: Ries: formation of a crater, impactites (lithic impact breccias, suevites, impact melt rocks, glass bomb, shatter cones and tektites), shock metamorphism of rocks and minerals (e.g. formation of high pressure phases, coesite, stishovite, diamond), lake sediments. Steinheim: formation of a crater, impactites (lithic impact breccias and shatter cones), ancient lake sediments, fossil fauna and flora.

Duration of event: The effect of the impacts were instant.

Impact on life: Both impacts only affected life that lived in close proximity to the target areas and presumably did not cause any species extinctions, and life recovered quickly afterwards (within decades) (Böhme et al. 2002).

\section{Background story:}

\section{Geological significance}

The Ries and Steinheim impact events occurred 14.8 million years ago (Buchner and Schmieder 2015). The impact structures are still preserved today. They are approximately $46 \mathrm{~km}$ apart, and aligned in a near NE - SW direction (see Fig. 4) (Miljković et al. 2013). 
Based on these observations it has been suggested that the two projectiles were orbiting each other before entering the Earth's atmosphere and then hit the two locations (Stöffler et al. 2002, Miljković et al. 2013). There are differences in how the two impact events are preserved with regards to crater shape (geomorphology), and the presence/absence of other geological features that are diagnostic of impacts such as ejecta blankets (lithic breccias and suevite), distal ejecta (tektites), and shatter cone structures in the target rocks (Figs 5, 6, 7) (Stöffler et al. 2002, Rasser 2014, Buchner and Schmieder 2015). The differences in crater diameter ( $24 \mathrm{~km}$ for Ries and $3.8 \mathrm{~km}$ for Steinheim) of the two impact events are the result of different projectile sizes; the one that hit Steinheim being much smaller (Stöffler et al. 2002). In both target areas the rock is composed of sedimentary strata (mainly porous limestone) underlain by a crystalline basement (e.g. hard granitic rocks) (Stöffler et al. 2002, Rasser 2014, Buchner and Schmieder 2015). The Steinheim crater has a central uplift (a hill structure formed by the rebound of the target rock shortly after the impact) whereas at Ries the central uplift has collapsed forming an inner ring within the crater basin (Stöffler et al. 2002, Buchner and Schmieder 2015). The Ries impact is famous because the ejecta blanket and distal ejecta (tektite strewn field) are extensively preserved, they cover an area of 200 to $450 \mathrm{~km}^{2}$ and fan outwards from the crater in an east-northeast direction (Stöffler et al. 2002, Buchner and Schmieder 2015). This widespread evidence has allowed scientists to reconstruct the likely velocity and angle of the Ries impact (Stöffler et al. 2002, Miljković et al. 2013). In contrast, the Steinheim crater shows no ejecta blanket, which is likely due to a higher degree of erosion in this area.

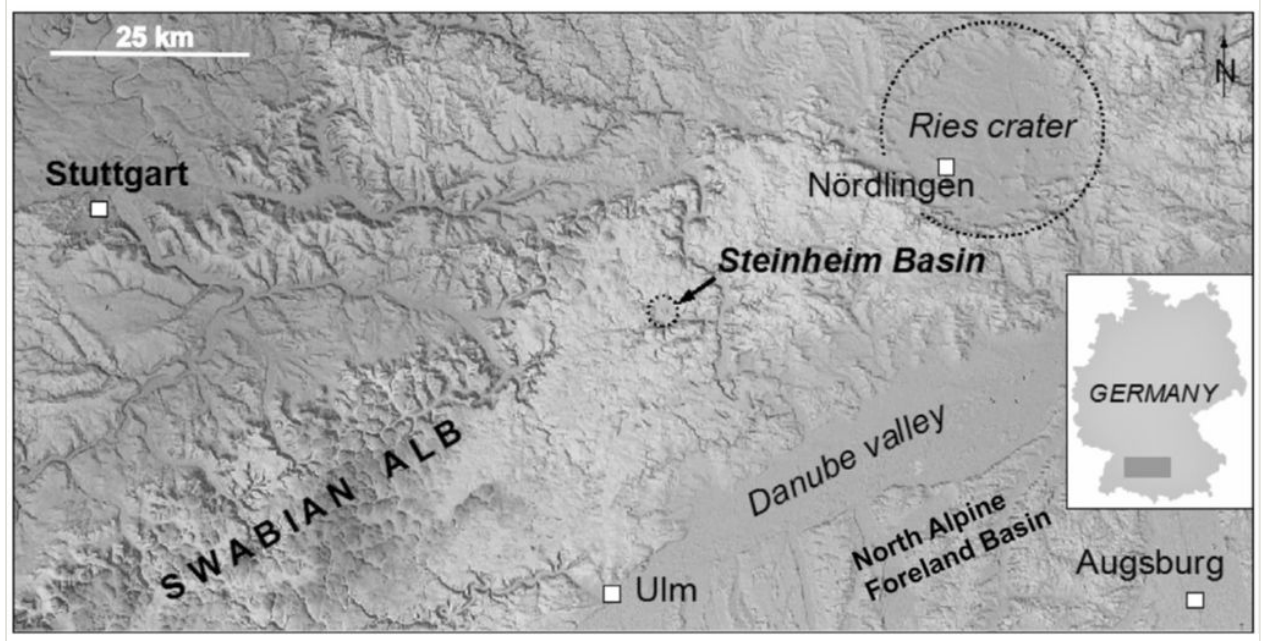

Figure 4. doi

Satellite image of the Ries and Steinheim craters. From Buchner and Schmieder (2015). 


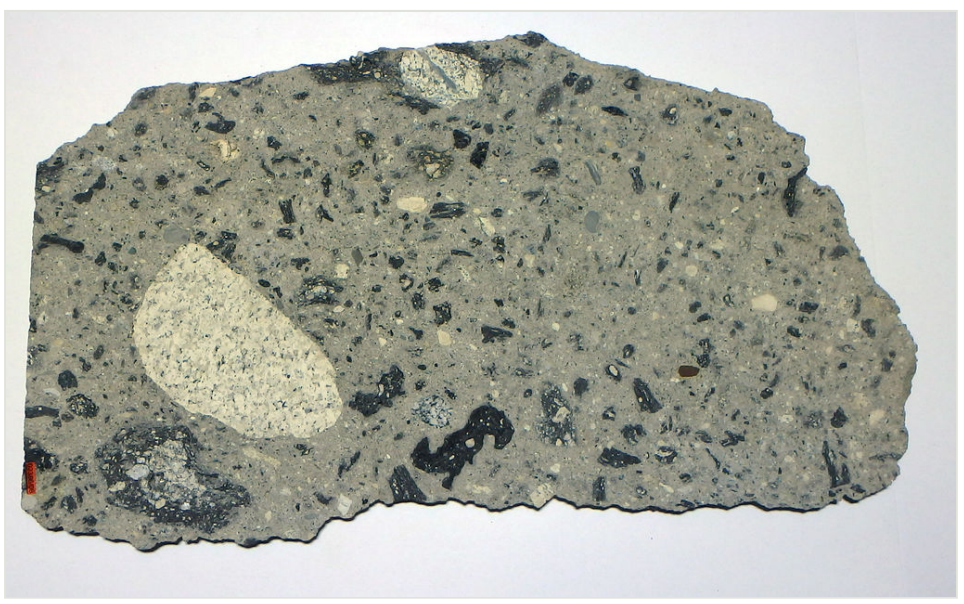

Figure 5. doi

Suevite specimen from the Ries impact event, collected from a suevite deposit that is part of the ejecta blanket about $4 \mathrm{~km}$ east of the crater rim. Suevite is a rock type that consists of larger angular target rock fragments surrounded by a matrix of smaller fragments and grains that have been melted and recrystallised due to pressures caused by the impact. Specimen size: $27 \times 15 \times 0.5 \mathrm{~cm}$. Museum für Naturkunde Berlin collection [Inventory number MFN_ PET_2008_02386], collected by M. Siebenschock, 1997, photo by R. T. Schmitt.

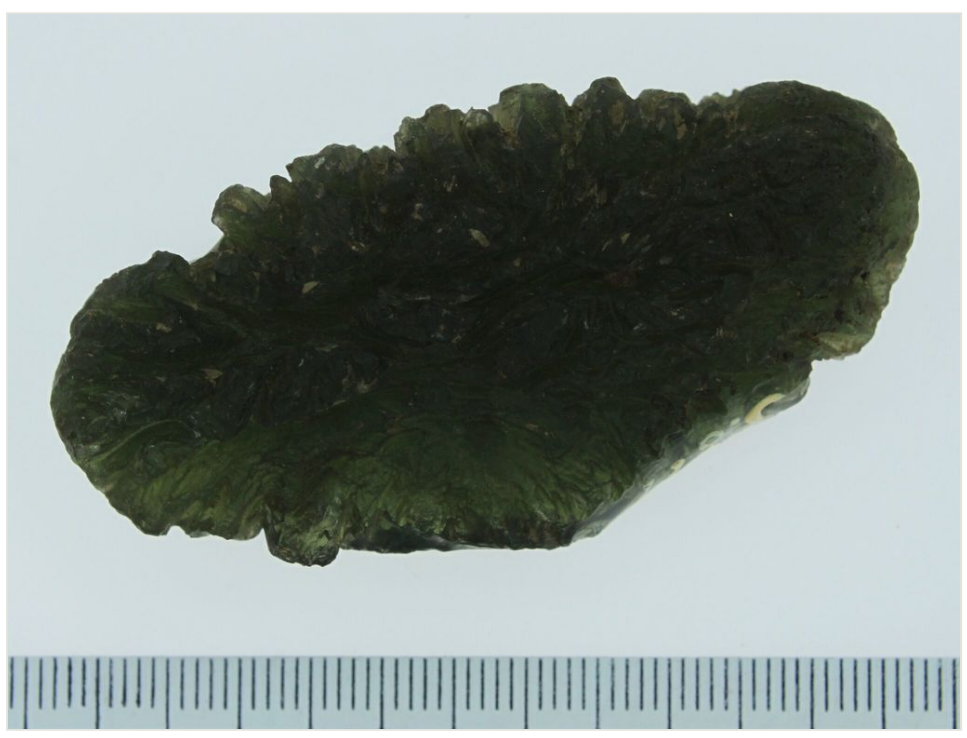

Figure 6. doi

A tektite that originates from the distal ejecta (strewn field) of the Ries impact, found in the Czech Republic. Tektites from the Ries impact are called moldavites. Ruler at the bottom of the image $=6.6 \mathrm{~cm}$ [Inventory number NHMV_J677]. Photo courtesy of L. Ferrière, Natural History Museum Vienna. 


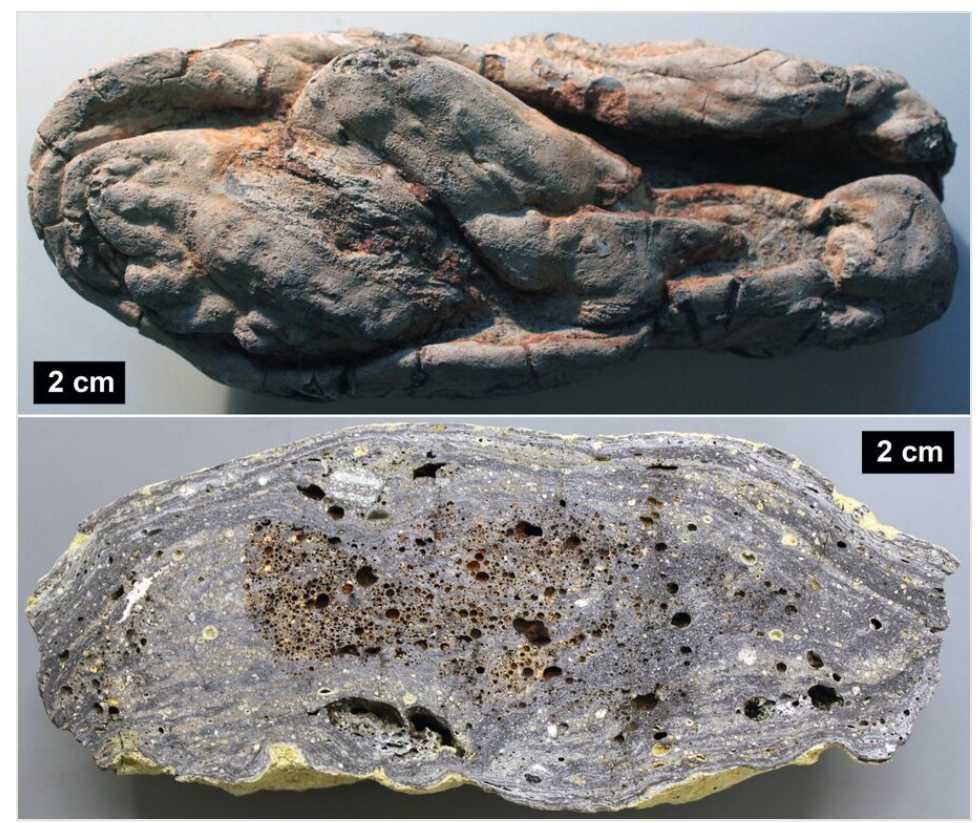

Figure 7. doi

Melt bomb specimens. Top image: a complete specimen with typical surface features; bottom image: section of a bomb showing flow texture and numerous vesicles (Aumühle quarry, Ries impact structure) [Inventory numbers NHMV_J3852 \& NHMV_O423]; Photo courtesy of L. Ferrière, Natural History Museum Vienna.

\section{$\underline{\text { Palaeontological significance }}$}

The target areas were rich with forests and fauna (Böhme et al. 2002). According to Böhme et al. (2002) life was only effected close to the impact sites with no extinction of species. Life is likely to have recovered quickly (within decades) (Böhme et al. 2002). The flora surrounding the Steinheim crater has been most recently described by Kovar-Eder and Schweigert (2018). However, the interesting story is not necessarily how the two impact events themselves affected life but rather how they helped initiate new habitats and life afterwards.

During the middle Miocene, lakes formed within the impact craters and they became an ideal habitat for fish, ostracods and snails. In the case of Steinheim many were endemic to the lake (Rasser 2014). Today the remains of these organisms are preserved within the lake sediments that fill the craters. The Steinheim crater became famous through the early studies by Hilgendorf (1863) and Hilgendorf (1867) on the gastropods preserved in the layers of lake sediments. These are an important contribution to our understanding of the processes of evolution, speciation and endemism (Rasser 2014). Franz Hilgendorf studied the lake sediments from the lowermost units to the top (i.e. from the oldest to the youngest sediments) and found that shell morphology changed through the different layers. Based on these observations and further analyses he classified the snails into species based on 
their shell morphology and produced the first ever palaeontological evolutionary tree for them. This evolutionary tree supported Darwin's theory on the origin of species (i.e. all species have descended from a common ancestor) (Figs 8, 9) (Rasser 2013). The Steinheim gastropod species evolved from a single non-endemic species from the genus Gyraulus (a form called aequeumbilicatus by Hilgendorf, now called Gyraulus kleini).

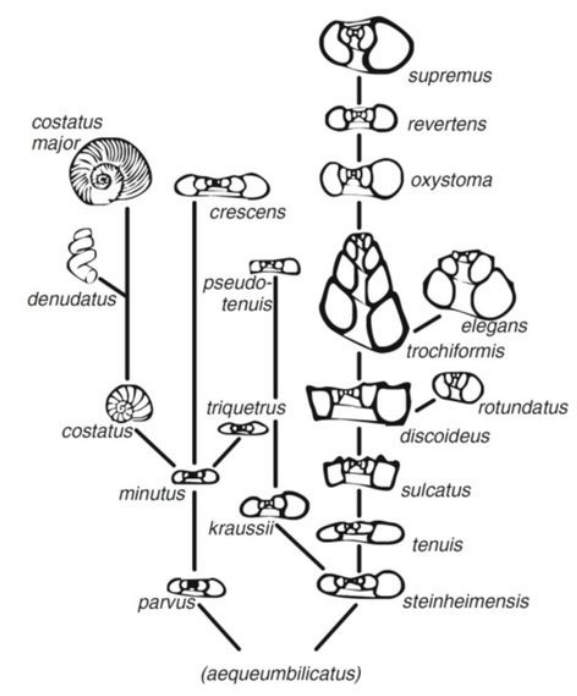

Figure 8. doi

A re-drawn version of Hilgendorf's original evolutionary tree of the Steinheim snail species (genus: Gyraulus). Image from Rasser (2014).

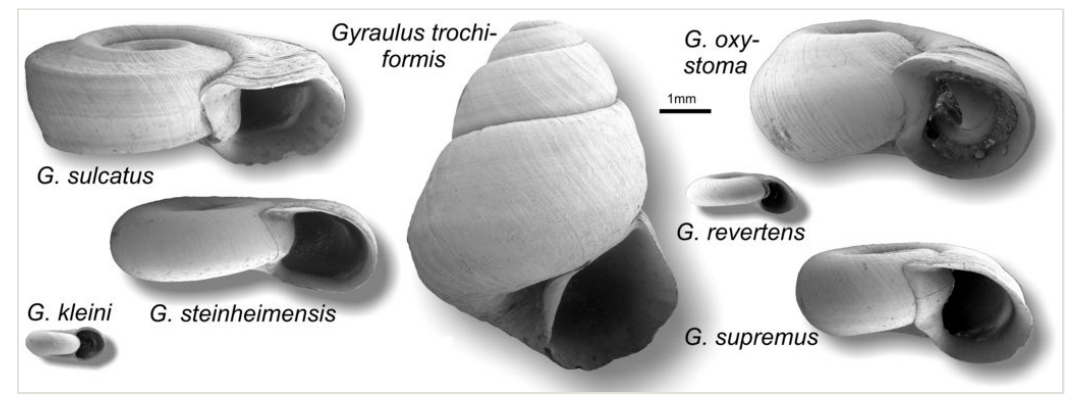

Figure 9. doi

Fossil snail species from Steinheim. Photo taken by M. Rasser, State Museum of Natural History Stuttgart.

The factors/processes which caused endemism, and evolution of the snails in the ancient lake are still largely unknown. Evolution of the gastropods may have been triggered by environmental changes in the lake such as water level and chemical changes (Rasser 2014). From recent studies, Rasser and Covich (2014), predation holes have been found in 
some snail shells and thus predator-prey interaction may have been one of the driving forces for their evolution. In terms of endemism one explanation is that migration from outside the lake could not take place due to ecological niches being already occupied.

\section{Other examples of local and regional scale impact events}

- Impactite collection of Eocene age, originating from Popigai (Russia) and housed at the Museum für Naturkunde Berlin.

- Impact collection (proximal) of Late Triassic age (206.9 million years), originating from Rochechouart (France) and housed at the Natural History Museum Vienna.

- Impactite collection (distal - tektites) of Pleistocene age (0.77-0.78 million year), originating from the Australasian strewnfield and housed at the Natural History Museum Vienna.

\section{Volcanic events}

\section{Santorini volcanic eruption}

Age: $1614 \pm 30$ B.C., Holocene (Friedrich 2006)

Modern location of event: Santorini, Greece

Location of collection: Natural History Museum Crete

Preservation type: Fossil flora - olive leaves and branches, volcaniclastic rock

Duration of event: Days/hours

Impact on life: The Minoan civilisation was destroyed by a tsunami triggered by the collapse of the volcano sides.

Background story: The Santorini eruption is considered as one of the most violent in historic times, 10 times bigger than Krakatau (1883) in Indonesia. The Volcanic Explosively Index (VEI) for this eruption is estimated at 7 which makes the Santorini eruption one of the largest in the last 20,000 years (Heiken and McCoy 1984). The eruption totally destroyed Santorini Island (or Strongili as it was known then), and created the present-day caldera. It also triggered a devastating tsunami that affected the central and eastern Mediterranean (Heiken and McCoy 1984).

Based on archaeological findings and relative dating, the eruption was for many decades considered to have happened around 1450-1500 B.C., and thus was considered the main reason for simultaneous collapse of the famous Minoan Civilisation and the destruction of its palaces (Friedrich 2006).

The finding of fossilised leaves and branches of olive trees (Fig. 10) among the ash deposits from the eruption on Santorini Island permitted radiocarbon dating, which gave a new age for the eruption at about $1614 \pm 30$ B.C. Based on this new dating, the majority of 
scientists believe that the consequences of the natural disaster following the Santorini Eruption and especially the tsunami, were responsible for the gradual collapse of the Minoan Civilization, which happened 150 years later with final destruction (due to other reasons) of its palaces (Friedrich 2006)

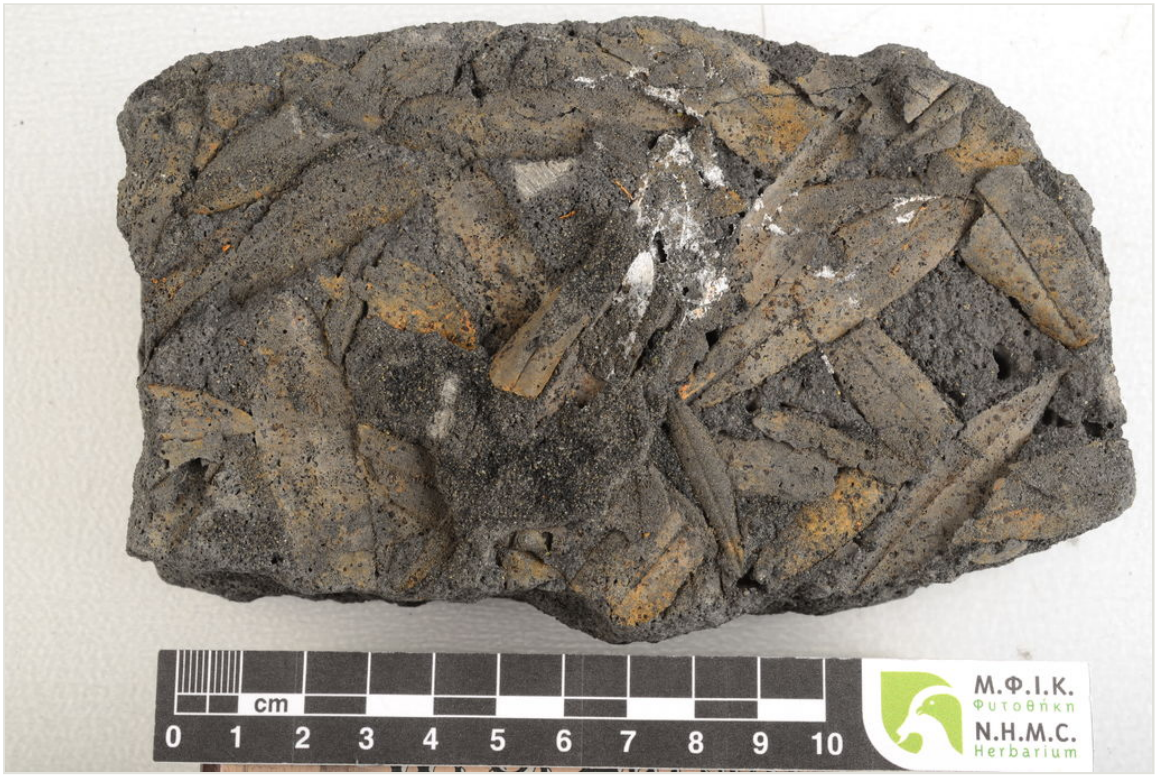

Figure 10. doi

Fossil olive leaves preserved within volcaniclastic rock from the Santorini eruption. Image courtesy of the Natural History Museum of Crete.

Analysis of the volcaniclastic rock units in which the olive leaves are preserved are important for understanding the processes and phases involved in the Santorini Eruption (Fig. 10). It has been estimated that the eruptive volume of ash was around $39 \mathrm{~km}^{3}$, based on the thickness of the volcaniclastic layers (Dominey-Howes and Minos-Minopoulos 2004). Scientists have studied the different volcanic rock units deposited from the eruption on the surrounding islands, in terms of the thickness of the layers, composition (pumice, ash and pyroclastic) and grain size (Friedrich 2013). They indicate at least three eruption phases, each with different hazards associated with them. The three different phases of the eruption were caused by changes in the morphology of the volcanic vent, the interaction of the magma with sea water, and the collapse of the roof of the volcano to form the caldera (Friedrich 2013). For example, the first phase of the eruption was explosive and sent an ash cloud into the stratosphere. During the second phase the magma interacted with water causing violent explosions. Reconstructing these different eruptive phases has been informative for disaster mitigation planners with regards to mapping out potential hazard zones, as well as raising awareness amongst policy makers and residents of the islands about possible future eruption scenarios (Dominey-Howes and Minos-Minopoulos 2004). 


\section{Carboniferous Plinian type eruption}

Age: Pennsylvannian (323.2 298.9 million years ago), Carboniferous (Sternberg 1820, Mašek 1973)

Modern location of event: Radnice, Central Czech Republic

Location of collection: Natural History Museum Prague

Preservation type: Palaeontological, fossil flora, volcanic ash layers

\section{Duration of event: Days}

Impact on life: A swamp forest close to the volcanic center was destroyed as a result of being covered by ash.

Background story: The Lower Radnice Coal horizon contains well preserved swamp vegetation and it is overlain by a 40-60 cm thick layer of coarse volcaniclastic sediments (containing a lot of feldspar) (Opluštil et al. 2009b, Opluštil et al. 2014, Sternberg 1820). This sediment is interpreted as being derived from a catastrophic volcanic eruption (Plinian type) during the Carboniferous Opluštil et al. (2009a), Sternberg (1820), Mašek (1973). The key characteristics of the eruption include ejection of a large amount of ash and pumice by continuous powerful gas-driven eruptions. Volcanic debris and hot gases were also ejected high into the stratosphere. The volcanic center is called the Altenberg-Teplice Caldera (ATC), it was a part of the Bohemian Massif and the largest known volcanic center in the region during the late Palaeozoic Mlčoch and Skácelová 2010. Remains of this volcano are preserved as porphyry dykes of granitic composition situated in areas between Teplice and Dresden near to Altenberg in the eastern Krušné Hory Mountains/Erzgebirge (on the border between the Czech Republic and Germany) (Mlčoch and Skácelová (2010). The high volume of ash compacted the vegetation and thus allowed for the excellent preservation of pre-eruption vegetation of the tropical coal swamp. More than 20 wholeplant species were detected and palaeo-ecologically interpreted (Opluštil et al. 2009a, Opluštil et al. 2009b, Opluštil et al. 2014). Among them a number of famous genera such as Lepidodendron (Fig. 11) have been described by Sternberg (1820). His work "Versuch einer geognostisch-botanischen Dararstellung der Flora der Vorwelt" is now considered as the foundation of modern palaeobotany.

\section{Other examples of local and regional scale volcanic events}

- $\quad$ A recent study by Petrone et al. (2016) (Natural History Museum London) on the chemical analysis of zoned crystals within igneous rock from Stromboli (Italy) has helped further the understanding of pre-eruptive magmatic processes, which is an important step towards being able to predict volcanic eruptions in the future. Although the paper does not mention museum collections it is an example of how museum archived rock samples could be re-studied using new techniques (Pers Comm. G. Miller, April 2018). 
- $\quad$ Regional rock collections of Quaternary age (regional scale event), originating from Campi Flegrei, Vesuvius/Monte Somme (Italy), housed at the Museum für Naturkunde Berlin (Germany).

- $\quad$ Plant fossils, of early Miocene age (local scale event), originating from Ipolytarnóc (Hungary), housed at the Hungarian Natural History Museum.

- The Royal Museum for Central Africa (Belgium) is studying the eruptive history of the Nyamulagira and Nyiragongo volcanoes located close to Goma city (Democratic Republic of Congo), at the border with Rwanda. Intensive field work and radiocarbon dating of rock samples from the museum's Earth science collection provided new evidence of the explosive activity of some volcanic cones identified in the region (Smets et al. 2013, Smets et al. 2015, Poppe et al. 2016).

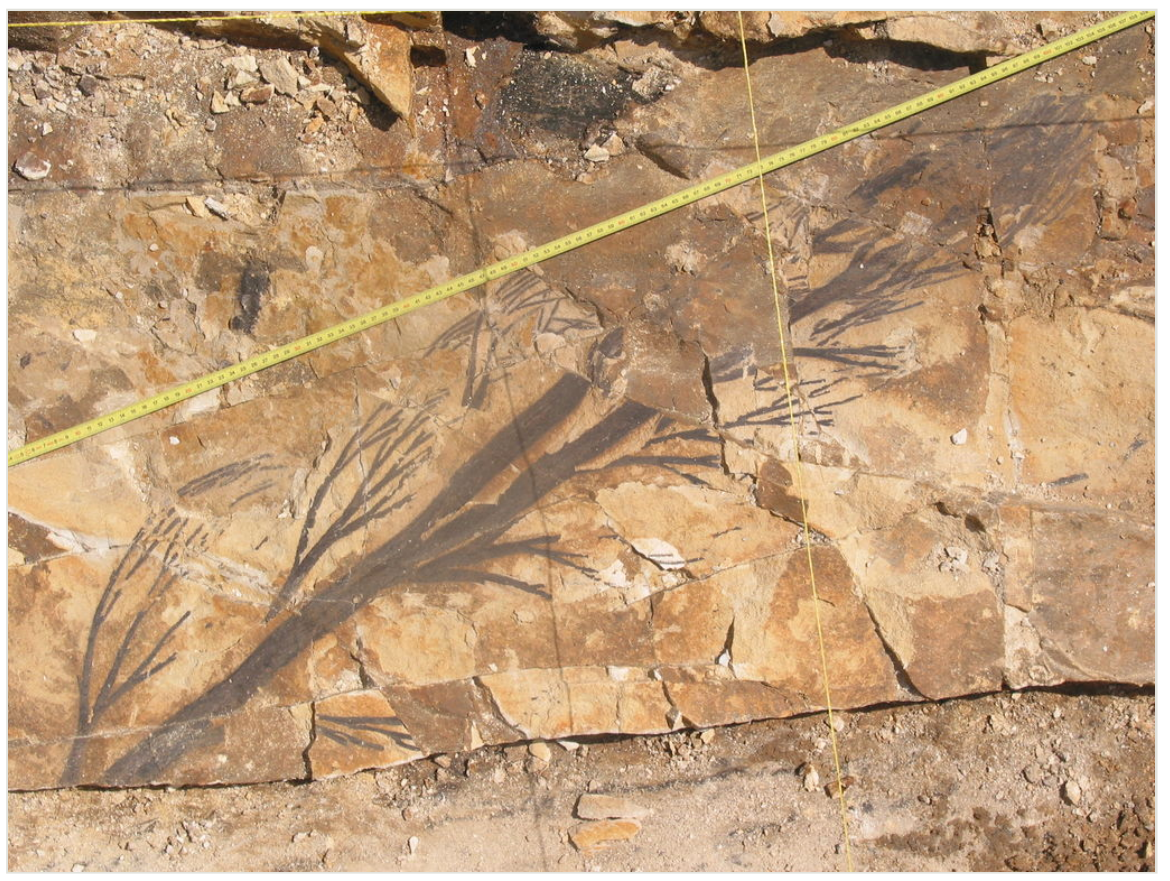

Figure 11. doi

Lepidodendron lycopodioides, terminal branch, Přívětice excavation season 2003, Photo taken by J. Dašková 2003, Natural History Museum Prague.

\section{Salinity crisis event}

\section{Messinian salinity crisis}

Age: Messinian (7.2-5.3 million years ago), Miocene (Krijgsman et al. 1999)

Modern location of event: Mediterranean Sea 
Location of collection: Natural History Museum Crete

Preservation type: Palaeontology (marine and terrestrial organisms), mineralogical (evaporite minerals)

\section{Duration of event: 600,000 years}

Impact on life: Extinction of marine organisms, turnover of terrestrial fauna. The collections identified here only show evidence of life prior to the event.

Background story: The Messinian is the last stage of the Miocene Epoch, which lasted from 7.2 to 5.33 million years ago. For the Mediterranean this period is related to one of the most catastrophic geological and meteorological events, the Messinian salinity crisis, which was caused by the isolation of the basin from the Atlantic Ocean (Harzhauser et al. 2007).

Following the closure of the marine connections to the Indian Ocean in the early Miocene (Harzhauser et al. 2007), the Mediterranean Sea was entirely separated from the world's oceans during the late Miocene, around 5.96 million years ago. Tectonic processes closed the last connections with the Atlantic in southern Iberia and north-western Africa, transforming the Mediterranean into a huge lake, similar to the Caspian Sea today (Spakman and Wortel 2004). For more than half a million years the Mediterranean suffered from intense evaporation, which was not completely compensated by the influx of fresh water from the river systems of the surrounding land masses and thus resulted in the deposition of evaporites such as rock salt, gypsum, and anhydrite. Large parts of the basin dried out completely while others became salt lakes, occasionally topped up by an upper layer of fresh to brackish water from fluvial runoff. Life in and around the Mediterranean Sea was strongly affected. The marine fauna and flora was severely diminished, although extinctions vary among taxa, ranging from 5-40\% (Berning 2006). In the terrestrial realm, acidification and sudden geographic changes led to a faunal turnover in land mammals (Alcover 2000). While desert conditions in the Mediterranean region caused extinctions of local faunas, African mammals made use of the newly existing land bridges to migrate northwards, replacing established species (van der Made et al. 2006, Domingo et al. 2014). Rise of the Mediterranean sea-level, due to flooding, then geographically isolated terrestrial species that survived the Messinian salinity crisis, leading to the evolution of new taxa.

The crisis ended 5.33 million years ago when new straits opened in the Gibraltar area and a huge flooding event took place. Nowadays evaporitic minerals dating back to the Messinian salinity crisis can be found in Crete (Fig. 12) as well as in many other islands and peripheral regions of the Mediterranean. Likewise, they are preserved on the sea floor across the Mediterranean (Krijgsman et al. 1999). The evaporite deposits represent 50 times the mineral content than is contained in the water of the modern day Mediterranean Sea. It is therefore estimated that during the crisis the Mediterranean Sea faced several cycles of evaporation and refilling from the Atlantic (Krijgsman et al. 1999). The causal mechanisms of these cycles are still open to scientific debate. 


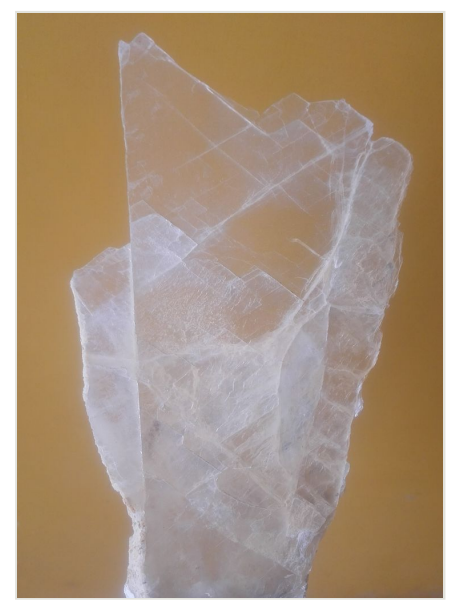

Figure 12. doi

A specimen of gypsum from the Messinian Salinity Crisis, found in Crete. Image courtesy of the Natural History Museum of Crete.

\section{Global scale hazards and disasters}

Global events recorded in the CETAF members' collections include, impact events, volcanism, and marine anoxia (see Suppl. material 1). These types of events often resulted in mass extinction and/or a transition in global climate and environments. For instance, at 66 million years ago (Cretaceous/Paleocene boundary) a large impact caused global climate change and marine anoxia resulting in the breakdown of biological systems (Alvarez et al. 1980, Bond and Grasby 2017). At the Permian/Triassic boundary (252 million years ago) there was widespread marine anoxia due to rapid global warming which may have been caused by large scale volcanism in Siberia (Bond and Wignall 2014, Bond and Grasby 2017). Below are detailed examples of two global events. In the "Hazard and Disaster Event Survey" climate change and mass extinction have been entered as types of global hazards.

\section{Marine anoxia event}

\section{Carnian pluvial episode (CPE)}

Age: Carnian (237-228.4 million years ago), Triassic (Dal Corso et al. 2015)

Modern location of event: Aşağiyaylabel locality-Taurus Mountains, southwest Turkey

Location of collection: Natural History Museum Vienna

Preservation type: Fossils - mass ammonite assemblages 
Duration of Event: Millions of years (Ruffell et al. 2015)

Impact on Life: The CPE caused widespread anoxic conditions in the oceans and thus caused widespread mortality of marine organisms in particular reef forming organisms (Dal Corso et al. 2015).

Background Story: The Carnian Pluvial Episode (CPE) refers to a time of global climate change from arid conditions that characterised most of the Triassic to high humidity and mega-monsoonal conditions (Dal Corso et al. 2015). During the Triassic the landmasses were amalgamated into a supercontinent called Pangaea. An intercontinental sea, called the Tethys, was situated between the Laurasian and Gondwanan domains of the supercontinent (Fig. 13, Dal Corso et al. 2015). One possible cause of the CPE may have been a large volume of $\mathrm{CO}_{2}$ being injected into the atmosphere due to flood volcanism that occurred as a result of ocean floor spreading during the opening of the southwestern domain of the Tethys region. The effects on the fauna and flora were widespread with extinctions both in the terrestrial and marine realm. In particular, the event was associated with widespread marine anoxia across the Tethys region. This was likely a consequence of heavy rainfall increasing weathering and the transport of nutrients from the land into the ocean, thus increasing the productivity of marine organisms and oxygen uptake. There was also a demise in carbonate platform production by reef forming communities and this was likely to have been caused by acidification of the oceans as a result of volcanism $\left(\mathrm{CO}_{2}\right)$ and marine anoxia (Dal Corso et al. 2015, Bond and Grasby 2017).

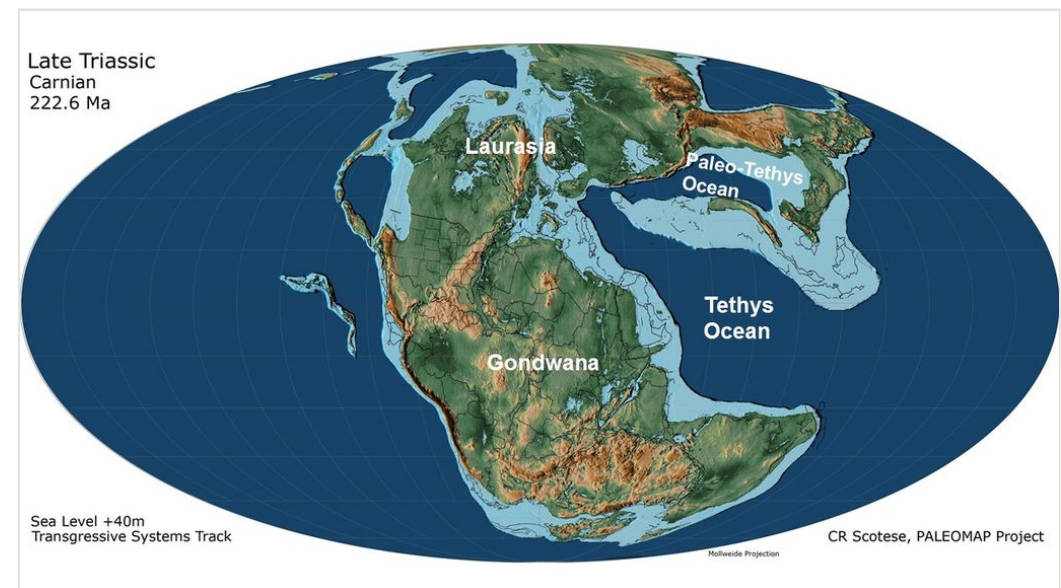

Figure 13. doi

Position of the continents configuration during the Carnian. Modified from Scotese (2014).

Fig. 14 shows a mass assemblage of fossil ammonites (Kasimlarceltites) from a sedimentary succession in southern Turkey (Aşağiyaylabel) of early to late Carnian age (Lukeneder et al. 2012, Lukeneder and Mayrhofer 2014). The sedimentary succession represents the breakdown of a carbonate platform within the western Tethys with lower rock units representing shallow carbonates that are overlain by deep marine black carbonates, 
shales and siliciclastic material. The mass ammonite beds occur within the black carbonate units and extensive research revealed that they contain 100 million specimens all belonging to the same species (Lukeneder and Mayrhofer 2014). The ammonite mass assemblage is not the result of mass mortality directly caused by CPE, as they predate it. Studies on the orientation of the ammonites and dip of the rock units in which they are contained have been useful for understanding how climate change can cause changes in sedimentation and the preservation of fossils on continental shelves. The ammonites were deposited on the continental shelf in shallow marine conditions but then they were transported to deeper marine settings by debris flows/gravity flows which were a common occurrence due to tectonic activity in the region and/or high frequency of storms during the monsoonal conditions of the Carnian (Lukeneder and Mayrhofer 2014).

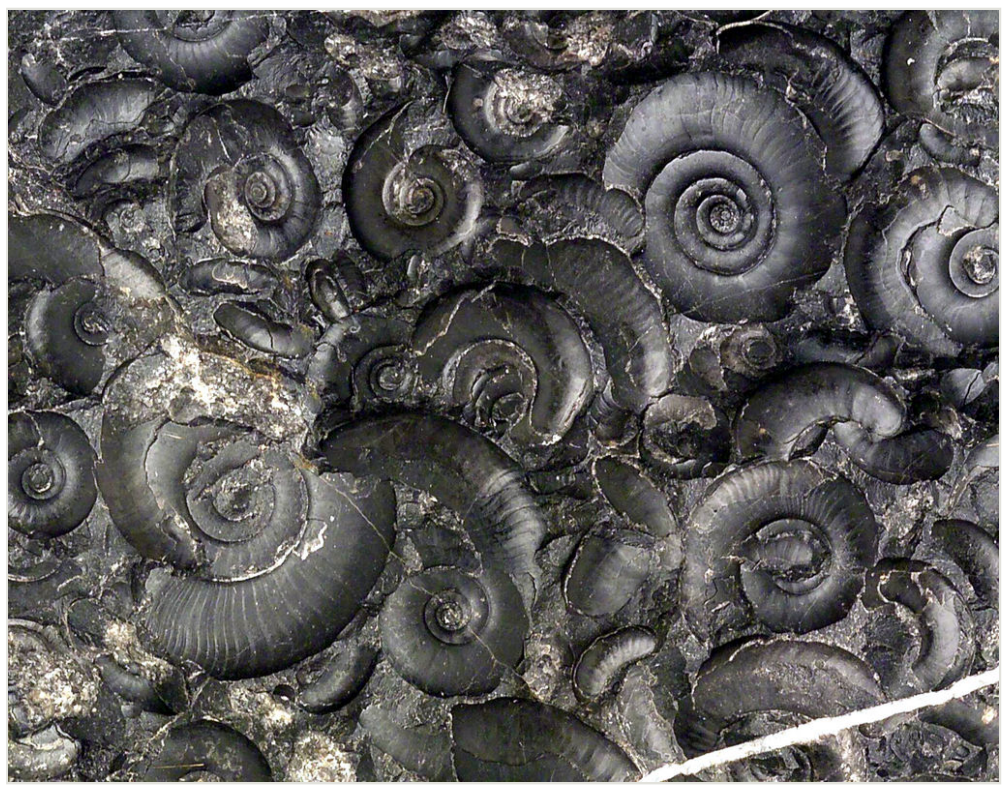

Figure 14. doi

A mass occurrence of the ammonite Kasimlarceltites from the Aşağiyaylabel locality. Photo taken by A. Lukeneder, Natural History Museum Vienna.

\section{Other examples of global scale marine anoxia events}

- $\quad$ Collection of Mesozoic vertebrates, including fishes of Carnian age (237-228.4 million years ago), Triassic, originating from Raibl in Austria, housed e.g. at the State Museum of Natural History Stuttgart.

- Conodont collections of Late Devonian age (383-359 million years ago), housed at Senckenberg Institute, Frankfurt.

- Collection of Mesozoic vertebrate samples of Toarcian age (183-174 million years ago), Jurassic, housed at the State Museum of Natural History Stuttgart. 


\section{Impact events (extraterrestrial projectiles)}

\section{Cretaceous/Paleocene impact event (Chicxulub)}

Age: 66 million years ago, Cretaceous/Paleocene (Bond and Grasby 2017)

Modern location of event: Impact location: Chicxulub, Yucatan, Mexico; knock-on effects were global

Location of collection: Museum für Naturkunde Berlin, Natural History Museum Vienna, Swedish Museum of Natural History, Natural History Museum London, National Museum of Natural Science Madrid

Preservation type: Formation of a crater, ca. $180 \mathrm{~km}$ in diameter (buried by younger sediments), impactites in the crater (Fig. 15) and ejecta blanket, global ash fall bed including shocked minerals and Iridium anomaly, fossil organisms (see Suppl. material 1).

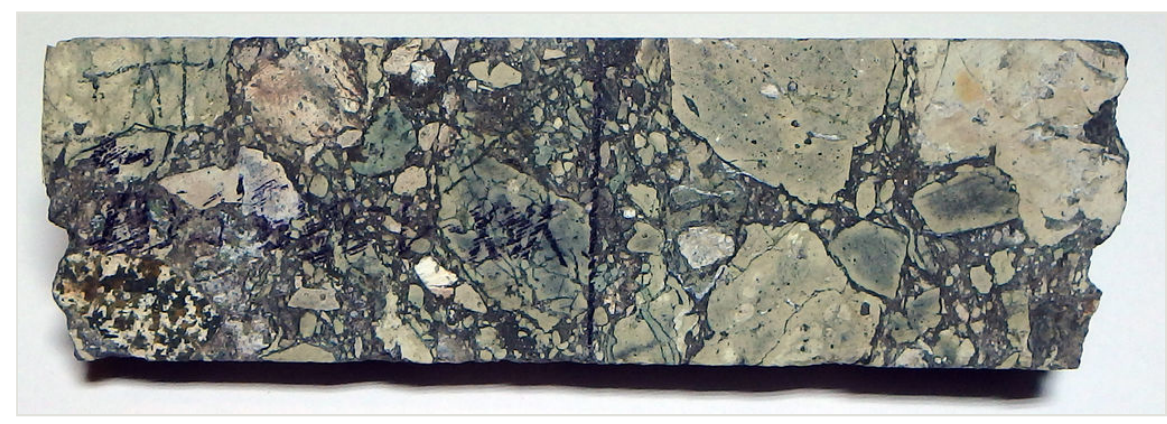

Figure 15. doi

Suevite specimen from ICDP - drill core Yaxcopoil-1 (2001-2002), depth $889.51 \mathrm{~m}$, Chixulub impact crater, Yucatan peninsula, Mexico. The suevite consists of melted and recrystallised fragments of the target rock. Specimen length $9.5 \mathrm{~cm}$. Museum für Naturkunde Berlin collection [Inventory number MFN_PET_2008_00058], photo by R. T. Schmitt.

Duration of event: The aftermath effects of the impact possibly lasted hundreds to thousands of years.

Impact on life: Around 76\% animal species (land and marine) became extinct (Sole and Newman 1999).

Background story: The Cretaceous/Paleocene impact event is associated with one of the most well-known extinction events in Earth's history because a substantial number of organisms on Earth became extinct, including the dinosaurs (Alvarez et al. 1980, Sole and Newman 1999, Kring 2007, Bond and Grasby 2017). The crater from this impact is situated on the Yucatan Peninsula, Mexico, is $180 \mathrm{~km}$ in diameter and the majority of it is under the ocean (Kring 2007). There is an ongoing debate amongst the Earth science community on whether the impact was capable of causing such devastation to life, or whether life was 
already stressed due to climate change caused by contemporary flood volcanism (Bond and Grasby 2017). In order to address this problem there has been extensive research on the crater morphology and the target rocks. The target rock types are a crystalline basement overlain by porous carbonates (limestones) and evaporites (anhydrite and gypsum) (Fig. 16). When the projectile hit the target, carbonates and sulphates of the sedimentary strata were vaporised, and gases (carbon and sulphur oxides) were released into the atmosphere along with dust.

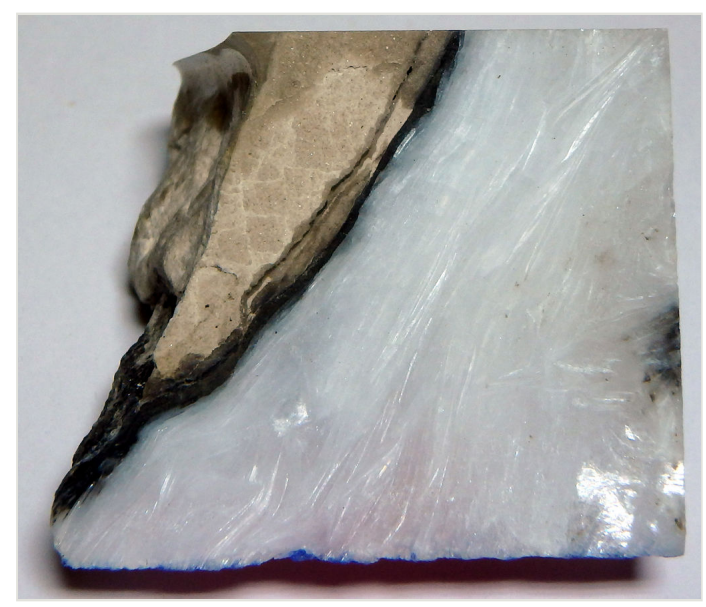

Figure 16. doi

Anhydrite specimen, ICDP-drill core Yaxcopoil-1 (2001-2002) depth $1376.11 \mathrm{~m}$, Chicxulub impact crater, Yucatan Peninsula, Mexico. Specimen length $2 \mathrm{~cm}$. Museum für Naturkunde Berlin collection [Inventory number MFN_PET_2008_00133], photo by R. T. Schmitt.

There was an initial cooling phase that was caused by sulphate gases and dust prohibiting penetration of sunlight, and as a result primary food producers like plants and marine plankton could not photosynthesise, leading to the collapse of the food chain (Kring 2007). A computer model study based on research of the crater rocks and the size of the projectile indicated that the cooling could have lasted for decades and global temperatures may have dropped by $27^{\circ} \mathrm{C}$ (Brugger et al. 2017).

\section{Other examples of global scale impact events}

- $\quad$ Core samples from the Sudbury Impact Structure (1849 million years old, Davis 2008); ca. $260 \mathrm{~km}$ max. diameter originally, Planetary and Space Science Centre (2018), housed e.g. at the University of Hamburg (Institute of Geology).

- Impactite collection from the Vredefort Impact Structure (2023 \pm 4 million years old, Kamo et al. (1996); ca. $160 \mathrm{~km}$ diameter today [ca. 250- $300 \mathrm{~km}$ originally], Planetary and Space Science Centre (2018), housed at the Museum für Naturkunde Berlin and the Natural History Museum Vienna. 


\section{Conclusions/what lessons can we learn for the future}

The "Hazard and Disaster Events Survey", which is summarised as a table below, reveals a wide range of different hazard and disaster event types recorded in the geological record that are documented in museum collections. This review presents seven exemplar hazard and disaster events detailing their location, duration, geographical scale, impact on life, and causal mechanisms if known. It highlights the potential value of studying the geological record for furthering our understanding of the causes and impacts of hazards and disasters at different geographical scales (regional and global scale). Furthermore it emphasises the importance of museum collections as a resource for hazard event research. Museum collections contain unique rock and fossil samples that have been archived from localities that are sometimes no longer accessible or may not be in the future; thus they allow the continued study of past hazard events and have the potential for new data to be obtained. Below are listed the conclusions and future lessons derived from the "Hazard and Disaster Event Survey" (presented in Suppl. material 1):

- The fossil and rock record can be useful in constraining dates when events occurred and thus help distinguish consequences of the hazards and disasters. For example, olive leaves and branches preserved during the Santorini eruption event helped constrain the date of the eruption, and that it triggered a tsunamis that initiated the demise of the Minoan civilisation.

- Fossils can be useful tools for investigating causal mechanisms of events. For instance potential environmental causes of the Bükkábrány flood event (e.g. climatic or tectonic) may in future be clarified by studying the climate signals stored in the fossil wood anatomy (e.g. growth ring analysis).

- In many cases regardless of the geographical scale of an event, life is present before and afterwards, however the type of life present might have changed (e.g. different plant species).

- $\quad$ Not all hazards in Earth's history have caused massive destruction to life; in some cases they have helped biodiversity and species evolution. The Steinheim impact event created a crater in which a long lasting lake developed and became a habitat for different types of organisms (e.g. gastropod), which evolved into new endemic species (only found in this lake).

- $\quad$ Some regional or global scale hazards and disasters such as explosive volcanism (with ash clouds), marine anoxia and flood events allow for the excellent preservation of fossils. For example ash fall from a Carboniferous Plinian eruption covered swamp vegetation and prevented it from decay. Another example is the Bükkábrány drowned forest. Excellently preserved fossils allow for more detailed reconstructions of past environments on Earth and help gain insight into the causal mechanisms and environmental impacts of some hazards.

- Many types of hazards and disasters that are recorded in the geological record also occur frequently in present times (e.g. volcanism, tsunamis, earthquakes and impacts). 
- Some hazards and disasters have not occurred for millions/thousands/hundreds of years but are a risk in the future e.g. widespread marine anoxia, sea level rise, and climate change. A large scale salinity crisis like the one that occurred in the Messinian has not occurred in present times but it is important to understand the mechanisms that caused such an event because it may happen in the near future.

- Hazards such as volcanic eruptions, impact events and flooding can modify significantly life at local, regional and global scale.

\section{Acknowledgements}

A special thank you to the museums/institutes in the Earth Science Group (ESG) of the Consortium of European Taxonomic Facilities (CETAF) that have contributed to the "Hazard and Disaster Event Survey" and supported the development of this publication: Estonian Geological collections, Fossil World Vienna, Hungarian Natural History Museum, Museum für Naturkunde Berlin, National Museum of Natural Sciences Madrid, Natural History Museum of Crete, Natural History Museum London, Natural History Museum Prague, Natural History Museum Vienna, Natural History Museum Sweden, Royal Museum for Central Africa, State Museum of Natural History Stuttgart, Senckenberg Institutes (Frankfurt, Görlitz, Dresden, Weimar), Center of Natural History Hamburg University (Institute of Geology). Ludovic Ferrière and Alexander Lukeneder (Natural History Museum Vienna) are gratefully acknowledged for providing photographs. Thank you to Christian Koeberl (Natural History Museum Vienna) for providing feedback and advice on an earlier version of this manuscript. Finally a thank you to CETAF for covering publication costs for this manuscript.

\section{Author contributions}

C.F., J.K-E., A.K., P.M., M.R. and J.K. Initially presented the idea of the "Hazard and Disaster Event Survey" for outreach purposes.

C.F., J.K-E., A.K., P.M., M.R., L.J.T., developed the idea of using the results from the "Hazard and Disaster Event Survey" to produce a publication aimed at the general public and natural science community.

L.J.T., analysed the results of the "Hazard and Disaster Event survey", selected the collection examples that have been used in the manuscript; approached Earth Science Group (of CETAF) members for information/images on examples; read/researched literature and evaluated information on the selected collections and the hazard/disasters that they documented. Also planned the content/layout of the manuscript, with the support of C.F., J.K-E., A.K., P.M., M.R. and R.T.S.

L.J.T., wrote the majority of the manuscript with the support of J.K-E., A.K., P.M., C.F., B.B, C.G.M., R.T.S., and C.M. 
M.R., developed the idea of Figure 1. which is a visualisation of the "Hazard and Disaster Event Survey" results. L.J.T. further developed the idea and designed Figure 1. with the support of J.K-E. and M.R.

C.F., contributed writing for the Santorini volcanic eruption and Messinian salinty crisis, which was edited and further expanded on by L.J.T.

B.B., Contributed writing for the Messinian salinity crisis.

J.K. Contributed writing for the Carboniferous plinian type eruption; edited by L.J.T.

B.B., B.E., C.F., A.K. J.K., C.M., C.G.M, M.R., R.T.S., provided information, references, expertise, and figures for the selected collections.

\section{Conflicts of interest}

The authors declare no conflict of interest.

\section{References}

- $\quad$ Alcover JA (2000) Vertebrate Evolution and Extinction on Western and Central Mediterranean Islands. Tropics 10 (1): 103-123. https://doi.org/10.3759/tropics.10.103

- $\quad$ Alvarez LW, Alvarez W, Asaro F, Michel HV (1980) Extraterrestrial Cause for the Cretaceous -Tertiary Extinction. Science 208: 1095-1108. https://doi.org/10.1126/ science.208.4448.1095

- $\quad$ Arizona State University Center for Meteorite Studies (2018) Arizona State University Center for Meteorite Studies. https://meteorites.asu.edu/meteorites/meteoriteappearance. Accessed on: 2019-1-07.

- Ball J (2008) Types of volcanic eruptions. https://geology.com/volcanoes/types-ofvolcanic-eruptions/. Accessed on: 2018-2-08.

- $\quad$ Barrière J, d'Oreye N, Oth A, Geirsson H, Mashagiro N, Johnson J, Smets B, Samsonov S, Kervyn F (2018) Single-Station Seismo-Acoustic Monitoring of Nyiragongo's Lava Lake Activity (D.R. Congo). Frontiers in Earth Science 6 https://doi.org/10.3389/ feart.2018.00082

- $\quad$ Berning B (2006) The cheilostome bryozoan fauna from the Late Miocene of Niebla (Guadalquivir Basin, SW Spain): environmental and biogeographic implications. Mitteilungen aus dem Geologisch-Paläontologischen Institut der Universität Hamburg, Hamburg, 156 pp.

- Böhme M, Gregor H, Heissig K (2002) The Ries and Steinheim Meteorite Impacts and their Effect on Environmental Conditions in Time and Space. In: Buffetaut E, Koeberl C (Eds) Geological and Biological Effects of Impact Events. Springer, Berlin, Heidelberg. https://doi.org/10.1007/978-3-642-59388-8 10 
- Bond DG, Grasby S (2017) On the causes of mass extinctions. Palaeogeography, Palaeoclimatology, Palaeoecology 478: 3-29. https://doi.org/10.1016/ j.palaeo.2016.11.005

- $\quad$ Bond DPG, Wignall PB (2014) Large igneous provinces and mass extinctions: An update. In: Keller G, Ker A (Eds) Volcanism, Impacts, and Mass Extinctions: Causes and Effects. 505. Geological Society of America https://doi.org/10.1130/2014.2505(02)

- Brugger J, Feulner G, Petri S (2017) Baby, it's cold outside: Climate model simulations of the effects of the asteroid impact at the end of the Cretaceous. Geophysical Research Letters 44 (1): 419-427. https://doi.org/10.1002/2016gl072241

- $\quad$ Buchner E, Schmieder M (2015) The Steinheim Basin impact crater (SW-Germany) Where are the ejecta? Icarus 250: 529-543. https://doi.org/10.1016/j.icarus.2014.12.026

- Centre for Research on the Epidemiology of Disasters (2009) The International Disaster Database. https://www.emdat.be/. Accessed on: 2018-6-20.

- Császár G, Kázmér M, Erdei B, Magyar I (2009) possible Late Miocene fossil forestPaleoPark in Hungary. In: Lipps JH, Grainer BR (Eds) PaleoParks - The protection and conser-vation of fossil sites worldwide. Carnets de Géologie / Notebooks on Geolog, Brest.

- Dal Corso J, Piero G, Newton R, Franceschi M, Roghi G, Caggiati M, Raucsik B, Budai T, Haas J, Preto N (2015) Carbon isotope records reveal synchronicity between carbon cycle perturbation and the "Carnian Pluvial Event" in the Tethys realm (Late Triassic). Global and Planetary Change 127: 79-90. https://doi.org/10.1016/ j.gloplacha.2015.01.013

- Davis D (2008) Sub-million-year age resolution of Precambrian igneous events by thermal extraction-thermal ionization mass spectrometer $\mathrm{Pb}$ dating of zircon:

Application to crystallization of the Sudbury impact melt sheet. Geology 36 (5): 383-386. https://doi.org/10.1130/g24502a.1

- Dominey-Howes D, Minos-Minopoulos D (2004) Perceptions of hazard and risk on Santorini. Journal of Volcanology and Geothermal Research 137 (4): 285-310. https:// doi.org/10.1016/i.jvolgeores.2004.06.002

- Domingo MS, Badgley C, Azanza B, DeMiguel D, Alberdi MT (2014) Diversification of mammals from the Miocene of Spain. Paleobiology 40 (02): 197-221. https:// doi.org/10.1666/13043

- $\quad$ English Oxford Living Dictionaries (2018) https://en.oxforddictionaries.com/. Accessed on: 2018-2-08.

- $\quad$ Erdei B, Dolezych M, Hably L (2009) The buried Miocene forest at Bükkábrány, Hungary. Review of Palaeobotany and Palynology 155: 69-79. https://doi.org/10.1016/ ¡.revpalbo.2009.01.003

- $\quad$ Erdei B, Magyari E (2011) Late Miocene plant remains from Bukkabrany, Hungary. Studia Botanica Hungarica 42: 135-151.

- $\quad$ Friedrich WL (2006) Santorini Eruption Radiocarbon Dated to 1627-1600 B.C. Science 312 (5773): 548-548. https://doi.org/10.1126/science.1125087

- $\quad$ Friedrich WL (2013) The Minoan Eruption of Santorini around 1613 B.C. and its consequences. In: Meller H, Bertemes F, Bork HR, Risch R (Eds) 1600 - Kultureller Umbruch im Schatten des Thera-Ausbruchs? 9. Tagungen des Landesmuseums für Vorgeschichte Halle, Halle (Saale), 37-48 pp.

- $\quad$ Gross M, Piller W, Scholger R, Gitter F (2011) Biotic and abiotic response to palaeoenvironmental changes at Lake Pannons' western margin (Central Europe, Late 
Miocene). Palaeogeography, Palaeoclimatology, Palaeoecology 312: 181-193. https:// doi.org/10.1016/j.palaeo.2011.10.010

- Gryc V, Sakala J (2010) Identification of fossil trunks from Bükkábrány newly installed in the Visitor Centre of the Ipolytarnóc Fossils Nature Reserve (Novohrad - Nógrád Geopark) in Northern Hungary. Acta Universitatis Agriculturae et Silviculturae Mendelianae Brunensis 58 (5): 117-122. https://doi.org/10.11118/actaun201058050117

- Harzhauser M, Kroh A, Mandic O, Piller W, Göhlich U, Reuter M, Berning B (2007) Biogeographic responses to geodynamics: A key study all around the Oligo-Miocene Tethyan Seaway. Zoologischer Anzeiger - A Journal of Comparative Zoology 246 (4): 241-256. https://doi.org/10.1016/i.jcz.2007.05.001

- Heiken G, McCoy F (1984) Caldera development during the Minoan eruption, Thira, Cyclades, Greece. Journal of Geophysical Research 89: 8441-8462. https:// doi.org/10.1029/ib089ib10p08441

- Hilgendorf F (1863) Bieträge zur Kenntnis des Süßwasserkalkes von Steinheim. Unpublished Dissertation. University of Tübingen, Tübingen.

- $\quad$ Hilgendorf F (1867) Über Planorbis multiformis im Steinheimer Süßwasserkalk. Monatsberichte der Königlich Preusischen Akademie der Wissenschaften zu Berlin 1866: 474-504.

- Huppert HE, Sparks RSJ (2006) Extreme natural hazards: population growth, globalization and environmental change. Philosophical Transactions of the Royal Society A: Mathematical, Physical and Engineering Sciences 364 (1845): 1875-1888. https://doi.org/10.1098/rsta.2006.1803

- $\quad$ IPCC (2014) Climate Change 2014: Synthesis Report. In: Team CW, Pachauri RK, Meyer LA (Eds) Contribution of Working Groups I, II and III to the Fifth Assessment Report of the Intergovernmental Panel on Climate Change. IPCC, Geneva, 151 pp.

- Kaiho K, Oshima N (2017) Site of asteroid impact changed the history of life on Earth: the low probability of mass extinction. Scientific Reports 7 (1). https://doi.org/10.1038/ s41598-017-14199-X

- Kamo SL, Reimold WU, Krogh TE, Colliston WP (1996) A $2.023 \mathrm{Ga}$ age for the Vredefort impact event and a first report of shock metamorphosed zircons in pseudotachylitic breccias and Granophyre. Earth and Planetary Science Letters 144: 369-387. https://doi.org/10.1016/s0012-821x(96)00180-x

- Kázmér M (2008) The miocene Bükkabrány fossil forest in Hungary - field observations and project outline. Hantkeniana 6: 229-244.

- Keeling R, Körtzinger A, Gruber N (2010) Ocean Deoxygenation in a Warming World. Annual Review of Marine Science 2 (1): 199-229. https://doi.org/10.1146/ annurev.marine.010908.163855

- $\quad$ Kovar-Eder J, Schweigert G (2018) Revision of the plant assemblage of Steinheim am Albuch (Baden-Württemberg, Germany, middle Miocene, reference locality of Mammal Neogene Zone MN 7). Bulletin of Geosciences 93 (4): 1-38. https://doi.org/10.3140/ bull.geosci.1695

- Krijgsman W, Hilgen FJ, Raffi I, Sierro FJ, Wilson DS (1999) Chronology, causes and progession of the Messinian salinity crisis. Nature 400: 652-655. https:// doi.org/10.1038/23231

- Kring D (2007) The Chicxulub impact event and its environmental consequences at the Cretaceous-Tertiary boundary. Palaeogeography, Palaeoclimatology, Palaeoecology 255: 4-21. https://doi.org/10.1016/j.palaeo.2007.02.037 
- Kvočka D, Falconer R, Bray M (2016) Flood hazard assessment for extreme flood events. Natural Hazards 84 (3): 1569-1599. https://doi.org/10.1007/s11069-016-2501-z

- $\quad$ Lukeneder A, Mayrhofer S (2014) Taphonomic implications from Upper Triassic mass flow deposits: 2-dimensional reconstructions of an ammonoid mass occurrence (Carnian, Taurus Mountains, Turkey). Geologica Carpathica 65 (5): 342-367. https:// doi.org/10.2478/geoca-2014-0024

- $\quad$ Lukeneder S, Lukeneder A, Harzhauser M, İslamoğlu Y, Krystyn L, Lein R (2012) A delayed carbonate factory breakdown during the Tethyan-wide Carnian Pluvial Episode along the Cimmerian terranes (Taurus, Turkey). Facies 58 (2): 279-296. https:// doi.org/10.1007/s10347-011-0279-8

- Magyar I, Geary DH, Müller P (1999) Paleogeographic evolution of the Late Miocene Lake Pannon in Central Europe. Palaeogeography, Palaeoclimatology, Palaeoecology 147: 151-167. https://doi.org/10.1016/s0031-0182(98)00155-2

- Mašek J (1973) Volcanic products of the Central Bohemian Carboniferous. Sbornik geologickych vëd, Geologie 24: 73-104.

- McGenity TJ, Oren A (2012) Hypersaline Environments. In: Bell EM (Ed.) Life at Extreme Environments, Organisms and Stratergies for Survival. CABI, Wallingford.

- Miljković K, Collins G, Mannick S, Bland P (2013) Morphology and population of binary asteroid impact craters. Earth and Planetary Science Letters 363: 121-132. https:// doi.org/10.1016/i.epsl.2012.12.033

- Mlčoch B, Skácelová Z (2010) Geometry of the Altenberg-Teplice Caldera revealed by the borehole and seismic data in its Czech part. Journal of Geosciences 55: 217-229. https://doi.org/10.3190/jgeosci.071

- $\quad$ Nelson SA (2015) Volcanoes, Magma, and Volcanic Eruptions. http://www.tulane.edu/ sanelson/Natural Disasters/volcan\&magma.htm. Accessed on: 2018-2-08.

- $\quad$ Opluštil S, Pšenička J, Libertín L, Bashforth A, Šimůnek Z, Drábková J (2009a) A Middle Pennsylvanian (Bolsovian) peat-forming forest preserved in situ in volcanic ash of the Whetstone Horizon in the Radnice Basin, Czech Republic. Review of Palaeobotany and Palynology 155: 234-374. https://doi.org/10.1016/ j.revpalbo.2009.03.002

- $\quad$ Opluštil S, Pšenička J, Libertín M, Bek J, Dašková J, Šimůnek Z, Drábková J (2009b) Composition and structure of an in situ middle Pensylvanian peat-forming plant assemblage buried in volcanic ash, Radnice Basin (Czech Republic. PALAIOS 24 (11): 726-746. https://doi.org/10.2110/palo.2008.p08-128r

- $\quad$ Opluštil S, Pšenička J, Bek J, Wang J, Feng Z, Libertin M, Šimůnek Z, Bureš J, Drábková J (2014) T0 peat-forming plant assemblage preserved in growth position by volcanic ash-fall: A case study from the Middle Pennsylvanian of the Czech Republic. Bulletin of Geosciences 89: 773-818. https://doi.org/10.3140/bull.geosci.1499

- $\quad$ Petrone CM, Bugatti G, Braschi E, Tommasini S (2016) Pre-eruptive magmatic processes re-timed using a non-isothermal approach to magma chamber dynamics. Nature Communications 7: 1-11. https://doi.org/10.1038/ncomms12946

- Planetary and Space Science Centre (2018) Earth Impact Database. http:// www.passc.net/EarthImpactDatabase/. Accessed on: 2018-9-10.

- $\quad$ Poppe S, Smets B, Fontijn K, Rukeza MB, Fikiri Migabo ADM, Milungu AK, Namogo DB, Kervyn F, Kervyn M (2016) Holocene phreatomagmatic eruptions alongside the densely populated northern shoreline of Lake Kivu, East African Rift: timing and hazard 
implications. Bulletin of Volcanology 78 (11): 78-82. https://doi.org/10.1007/ s00445-016-1074-8

- $\quad$ Rasser M (2013) Darwin's dilemma: The Steinheim snails' point of view. Zoosystematics and Evolution 89 (1): 13-20. https://doi.org/10.1002/zoos.201300002

- Rasser M (2014) Evolution in isolation: the Gyraulus species flock from Miocene Lake Steinheim revisited. Hydrobiologia 739 (1): 7-24. https://doi.org/10.1007/ s10750-013-1677-4

- $\quad$ Rasser M, Covich A (2014) Predation on freshwater snails in Miocene Lake Steinheim: a trigger for intralacustrine evolution? Lethaia 47 (4): 524-532. https://doi.org/10.1111/ let.12078

- $\quad$ Ruffell A, Simms MJ, Wignall PB (2015) The Carnian Humid Episode of the late Triassic: a review. Geological Magazine 153 (02): 271-284. https://doi.org/10.1017/ s0016756815000424

- $\quad$ Schmieder M, Kennedy T, Jourdan F, Buchner E, Reimold WU (2018) A high-precision 40Ar/39Ar age for the Nördlinger Ries impact crater, Germany, and implications for the accurate dating of terrestrial impact events. Geochimica et Cosmochimica Acta 220: 146-157. https://doi.org/10.1016/i.gca.2017.09.036

- Scotese CR (2014) Atlas of Middle \& Late Permian and Triassic Paleogeographic Maps, maps 43-48 from Volume 3 of the PALEOMAP Atlas for ArcGIS (Jurassic and Triassic) and maps 49-52 from Volume 4 of the PALEOMAP PaleoAtlas for ArcGIS (Late Paleozoic). Mollweide Projection, PALEOMAP Project. Evanston, I.

- Smets B, d'Oreye N, Kervyn F, Kervyn M, Albino F, Arellano SR, Bagalwa M, Balagizi C, Carn SA, Darrah TH, Fernández J, Galle B, González PJ, Head E, Karume K, Kavotha D, Lukaya F, Mashagiro N, Mavonga G, Norman P, Osodundu E, Pallero JLG, Prieto JF, Samsonov S, Syauswa M, Tedesco D, Tiampo K, Wauthier C, Yalire MM (2013) Detailed multidisciplinary monitoring reveals pre- and co-eruptive signals at Nyamulagira volcano (North Kivu, Democratic Republic of Congo). Bulletin of Volcanology 76: 78. https://doi.org/10.1007/s00445-013-0787-1

- $\quad$ Smets B, Kervyn M, d'Oreye N, Kervyn F (2015) Spatio-temporal dynamics of eruptions in a youthful extensional setting: Insights from Nyamulagira Volcano (D.R. Congo), in the western branch of the East African Rift. Earth-Science Reviews 150: 305-328.

https://doi.org/10.1016/j.earscirev.2015.08.008

- $\quad$ Sole RV, Newman M (1999) Patterns of extinction and biodiversity in the fossil record. The Earth System: Biological and Ecological Dimensions of Global Environmental Change 2: 297-301.

- $\quad$ Spakman W, Wortel R (2004) A Tomographic View on Western Mediterranean Geodynamics. The TRANSMED Atlas. The Mediterranean Region from Crust to Mantle. https://doi.org/10.1007/978-3-642-18919-7 2

- $\quad$ Sternberg KM (1820) Versuch einer geognostisch-botanischen Darstellung der Flora der Vorwelt. In Kommission im Deutschen Museum, in Leipzig bei Fr. Fleischer.

- $\quad$ Stern C (2004) Active Andean volcanism: its geologic and tectonic setting. Revista geológica de Chile 31 (2): 161-206. https://doi.org/10.4067/s0716-02082004000200001

- Stöffler D, Artemieva N, Pierazzo E (2002) Modeling the Ries-Steinheim impact event and the formation of the moldavite strewn field. Meteoritics \& Planetary Science 37 (12): 1893-1907. https://doi.org/10.1111/j.1945-5100.2002.tb01171.x 
- United Nations Office for Disaster Risk Reduction (2009) UNISDR terminology on disaster risk reduction. https://www.unisdr.org/we/inform/publications/7817. Accessed on: 2018-8-21.

- United States Geological Survey (2018) Summary of volcanic hazards from Kīlauea eruptions. https://volcanoes.usgs.gov/volcanoes/kilauea/extra/hazards.pdf. Accessed on: 2018-8-21.

- $\quad$ van der Made J, Morales J, Montoya P (2006) Late Miocene turnover in the Spanish mammal record in relation to palaeoclimate and the Messinian Salinity Crisis. Palaeogeography, Palaeoclimatology, Palaeoecology 238: 228-246. https:// doi.org/10.1016/i.palaeo.2006.03.030

- Wauthier C, Cayol V, Kervyn F, d'Oreye N (2012) Magma sources involved in the 2002 Nyiragongo eruption, as inferred from an InSAR analysis. Journal of Geophysical Research: Solid Earth 117: 1-20. https://doi.org/10.1029/2011jb008257

\section{Supplementary material}

\section{Suppl. material 1: Hazard and Disaster Event Survey doi}

Authors: Laura J Tilley, Boglárka Erdei, Charalampos Fassoulas, Andreas Kroh, Jiři Kvaček, Patricia Mergen, Caroline Michellier, C Giles Miller, Michael Rasser, Ralf T Schmitt, Johanna Kovar-Eder

Data type: Survey

Brief description: Presence data of Earth Science Museum Collections in Europe that document hazard and disaster events. This is an incomplete dataset and will continue to expand. Filename: Hazard and Disaster Events Survey.csv - Download file (11.40 kb) 